ELORE (ISSN 1456-3010), vol. 19 - 2/2012.

Julkaisija: Suomen Kansantietouden Tutkijain Seura ry.

[http://www.elore.fi/arkisto/2_12/granbom-herranen.pdf]

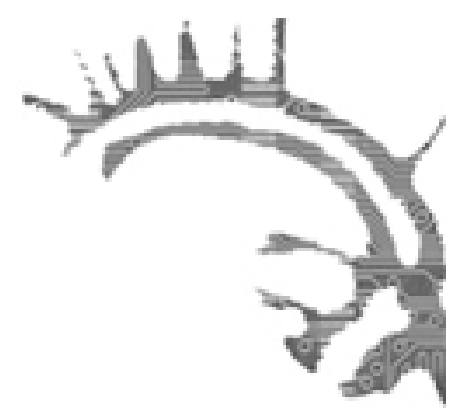

Katsaus

\title{
SUOMALAISEN SANANLASKUTUTKIMUKSEN AIKAKAUDET
}

\section{Liisa Granbom-Herranen}

Suomalaisilla sanalaskuilla on aina ollut kiinteä yhteys suomalaisen yhteiskunnan muutoksiin sekä yleismaailmallisiin virtauksiin. Kirkon ja valtion suhde vaikutti sananlaskujen muistiin merkitsemiseen jo 1500-luvulta alkaen. 1800-luvun lopulta 1900-luvun puoliväliin asti oli taloudellisella, yhteiskunnallisella ja ideologisella rakenteiden muutoksella vaikutusta perinteiden tutkimukseen Suomessa. Euroopan yhdistymisen myötä on 2000-luvulla ollut jälleen havaittavissa tarve oman kansallisen perinteen tutkimiseen. Tässä katsauksessa tarkastelen suomalaista sananlaskututkimusta ja sen kanssa rinnan toteutettua sananlaskujen keruuta suhteessa oman aikansa murroskausiin.

\section{ARKIPÄIVÄISET SANANLASKUT}

Arjen merkitys ja siihen kohdistuvan tutkimuksen suosio korostuvat yhteiskunnallisissa murroksissa (Jokinen 2005, 9). Ajankohdat, jolloin suomalaisten sananlaskujen tutkimus on ollut voimakkaan mielenkiinnon kohteena, ovat liittyneet suomalaisen yhteiskunnan murrosvaiheisiin. Tämä ei kerro varsinaisesta sananlaskujen käytön yleisyydestä juuri näinä aikoina, vaan kansanperinne korostuu kansakunnan tai kieliryhmän hakiessa omaa itseään ja omaa menneisyyttään. Kyseessä on ryhmän olemassaolon tai sen kehityksen kannalta keskeiseksi koettu tapahtuma, joka on usein yhteydessä joko yleismaailmalliseen tai lähialueiden tilanteeseen ja siinä koettuihin muutoksiin. (Honko 1979, 142; Dorson 
$1963,96$.$) Yleisesti ottaen on suomalaisen perinteen tutkimus ollut vahvasti sidoksissa$ nationalistisiin pyrkimyksiin (Wilson 1978, 51).

Sananlaskut ovat osa jokapäiväistä perinnettä. Suomessa sananlaskujen tutkimuksella on ollut erityisasema kansanrunoudentutkimuksessa ja sittemmin kulttuurin tutkimuksessa. Sananlaskujen yhteydessä tulee erottaa toisistaan niiden keruu, paremiografia, ja tutkimus eli paremiologia, joista jälkimmäinen on verrattain nuorta - olkoonkin, että suomalaisen akateemisuuden historiassa kansanrunoudentutkimus kuuluu vanhimpien oppituolien joukkoon. Keruuvaiheen merkitystä ei pidä väheksyä, koska tutkimus tukeutuu keruun tuottamaan aineistoon.

Folkloristisesta näkökulmasta katsottuna sananlasku on lyhyt ja suhteellisen itsenäinen väite, käsky tai toteamus, jonka ihmiset tuntevat ja jota he käyttävät jokapäiväisessä puheessa tai puheen kaltaisessa kirjoituksessa. Paremiologia tuntee ja käyttää useita erilaisia sananlaskun määritelmiä. ${ }^{1}$ Kuten sananlaskututkimuksella, on sananlaskun määrittelylläkin aina ollut yhteys kulloiseenkin aikaan ja sen tarpeisiin. Tieteenalat käsittelevät sananlaskua toisistaan poikkeavasti. Määrittelyjä löytyy yhtä paljon kuin tieteenaloja (Grzybek 1987, 44) tai tutkijoita (Mieder 2004, 2-3). Suomalaisen paremiologian kieli on tähän päivään asti ollut ensisijaisesti suomi. Pienen kielialueen sisäinen tutkimus on mahdollistanut oman tutkimuskäsitteistön käytön, esimerkiksi jaottelua sananparsiin ja sananlaskuihin ei muilta kielialueilta löydy. Käsitteet yksinkertaistuvat, kun tutkimusyhteydet kansainvälistyvät entisestään: käsitteet"sananlasku" ja "sananparsi" ovat englanniksi yksi ja sama käsite, "proverb". Tutkimuksen kohteena sananlasku kuuluu yleensä folkloristiikan ja kielten tutkimuksen piiriin. Folkloristiikassa kohteena on usein sananlaskujen käyttö puhutussa arkikielessä, kun taas kielitieteissä hyödynnetään pääsääntöisesti kirjallisia lähteitä (Granbom-Herranen 2010b, 216; 201 1, 287; Grzybek 2011). Sananlaskujen tarkastelu sekä perinteessä että kirjallisuudessa kuuluvat olennaisesti suomalaiseen paremiologiaan. Keskeistä on ollut tunnistaa sananlaskun käyttäjät, " kansa". Kuten Lauri Honko huomautti, sitä kansaa, jota kansallisromantiikan aika etsi, ei enää ole - jos on koskaan ollutkaan. Nykyisin folkloristiikan näkökulmasta sananlaskujen käyttäjäryhmä voi määrittyä sosiaalisen aseman, ammatin, etnisen taustan, kielen tai minkä hyvänsä ryhmää yhdistävän piirteen kautta. Kansa on korvautunut ryhmän jäsenyydellä. (Honko 1998, 1; Harris-Lopez 2003, 105.)

\section{Puheesta paperille}

Suomalaisen sananlaskun erityispiirre on olla suomenkielinen ilmaus. ${ }^{2}$ Tämän vuoksi se vielä toiseen maailmansotaan asti oli ensisijaisesti suullisessa käytössä, kun taas mo-

1 Sananlaskun määrittelemisen haasteesta, ks. esim. Mieder 2004.

2 Suomessa on myös arkikielisiä ruotsinkielisiä sananlaskuja, joista puhutaan suomenruotsalaisina sananlaskuina. Suomessa ennen itsenäisyyttä kirjalliseen perinteeseen kuuluvat sananlaskut puolestaan ovat pääosin joko ruotsalaisia tai suomenruotsalaisia sananlaskuja. 
nilla Keski-Euroopan kielialueilla sananlaskujen on katsottu kuuluneen ensisijaisesti kirjallisuuteen (esim. Hauser 2012; Schmale 2012). Folkloristinen paremiografia on keskittynyt suullisen perinteen tallentamiseen. Alkuvaiheessa, 1500-luvulla suomen kieli oli puhekieli, jolle ei ollut olemassa kirjallista muotoa. Myös Raamatun sananlaskut ovat tulleet suomenkieliselle kansanosalle tunnetuksi puhutussa muodossa, osana kansankielisiä saarnoja. Usein kansainvälisessä ja etenkin vertailevassa sananlaskututkimuksessa keskeisiksi ovat muodostuneet kerätyt ja julkaistut sananlaskukokoelmat sekä kaunokirjallisuuden tekstit (Prahlad 1996, 5). Sananlaskututkimuksella on ollut toiset lähtökohdat maissa, joissa painettuja kokoelmia sekä muuta kirjallista aineistoa on ollut käytettävissä jopa vuosisatojen takaa (Kuusi 1990, 451-452). Vuoteen 1959 mennessä tallennetut suomalaiset sananlaskut löytyvät pääosin kolmesta teoksesta: R. E. Nirvin ja Lauri Hakulisen kokoelmasta vuodelta 1948 (1953), Matti Kuusen toimittamasta julkaisusta vuodelta 1953 (1990) sekä Kari Laukkasen ja Pekka Hakamiehen kirjasta vuodelta 1978 (1997).

Sananlaskukokoelmia on julkaistu suomeksi niiden tallentamisen alkuvaiheista lähtien, mutta niiden vaikutus kansan käyttämään kieleen oli vähäistä, sillä lukutaito suomenkielisen väestön keskuudessa ei ollut yleistä. On mahdollista, että monessa tapauksessa sananlaskujen kerääjät eivät olekaan tarkoittaneet keräyksiään ainoastaan arkistoitaviksi. Tallentamiseen liittyvillä nostalgialla sävyttyneillä tunteilla on voinut olla joko tietoisesti tai tiedostamatta merkitystä sille, mitä tallennettiin. Valmiissa sananlaskujulkaisuissa on aina mukana kerääjän (tai julkaisijan) päätös mukaan otetusta aineistosta. Elias Lönnrot totesi vuonna 1842 ottaneensa mukaan kaiken "paitsi mitkä olivat itsestään mielettömiä vertauksia, eli muuten rietassanaisia, rivoja, joillen ei ole taittu siaa antaa" (Lönnrot 1981, 8) ilmeisesti pitämättä tätä ongelmana. Vaikka seuraava käyttäjä saattaa löytää kokoajan maininnat huomautuksista poisjätetyistä aineistoista (esim. Kuusi 1971, 100), nämä rajaukset jäävät usein huomiotta johtopäätöksiä tehtäessä. Seuraavat tutkijat tukeutuvat aikaisemmin tehtyihin johtopäätöksiin.

Sananlaskujen - samoin kuin yleensä perinteen - tallentaminen on ollut pääosin miestutkijoiden ja miestutkimusmatkailijoiden tuottamaa aineistoa. Rajoittuminen miesnäkökulmaan ei ole koskenut ainoastaan suomalaista keräysjärjestelmää (Obelkevich 1994, 222). Suomessa niin sananlaskujen kertojat kuin niiden kerääjätkin olivat aina 1900-luvulle asti useimmiten miehiä. Oletettavaa on, että kerääjät kohtasivat matkoillaan pääasiallisesti miehiä ja miesten arjen. Suomalaisiin sananlaskuihin nainen on yleensä liitetty lähinnä luettaessa niistä naista ja naiseutta väheksyviä sävyjä (Kuusi 1971; Granbom-Herranen 2010a). Suomalaisen Kirjallisuuden Seuralle aineistoa toimittaneista kansankerääjistä oli 1800-luvun lopulla ja 1900-luvun alussa noin viisi prosenttia naisia, mutta organisoituihin kenttätöihin ensimmäiset naiset osallistuivat vuonna 1916 (Mikkola 2012). Huolimatta siitä, että naiset osallistuivat kansanrunouden kenttätyöhön, ei heitä siihen juurikaan rohkaistu. Keruuprojekteissa naiset toimivat miesten apulaisina aina 1970-luvulle asti. (Apo ym. 1998, 22.) Sen, että varsin suurella todennäköisyydellä puolet suomenkielisestä väestöstä on jäänyt sananlaskujenkin tallentajien tavoittamattomiin, voidaan olettaa vaikuttaneen siihen, mitä sananlaskutallenteet sisältänät ja mihin tutkimus pääosin tukeutuu.

Aikana, jolloin Suomen alue kuului Ruotsin valtakuntaan ennen vuotta 1809, heräsi 
kiinnostus sananlaskujen keräämiseen ja silloin koottiin ensimmäiset suomenkieliset sananlaskuaineistot (ks. Liite 1). Uskonpuhdistukseen liittynyt aatteellinen murros loi edellytykset suomalaisen kansan kulttuurin olemassaolon näkemiselle. Suomen kirjakielen luominen oli kenties tärkein tätä tukeva toiminta. Ensimmäisenä suomenkielisten sananlaskujen muistiinmerkitsijä on Mikael Agricola. Rucouskiria Bibliasta (Agricola 1544) sisältää myös suomalaisia sananlaskuja. Saksalaisilla julkaisuilla oli esikuvallinen vaikutus Agricolan kiinnostukseen suomenkielisiä sananlaskuja kohtaan - Johannes Agricolan ja Sebastian Franckin julkaisemat kokoelmat 1500-luvun puolivälissä olivat kansankielisiä, saksankielisiä. (Hautala 1954, 26-27, 34.) Ennen kaikkea Agricolan oppi-isä Martin Luther oli innokas sananlaskujen käyttäjä sekä puheessaan että kirjoituksissaan. Hänen mukaansa sananlaskut ovat lähtöisin Jumalan teoista, vaikka ne eivät ole Jumalan sanaa. Lutherin ajatus sananlaskujen perustumisesta Jumalan sanaan siirtyi Agricolan teksteihin. (Hautala 1954, 27, Kuusi 1990, 452.)

Henrik Floriniuksen vuonna 1702 ilmestynyt kokoelma Wanhain Suomalaisten Tawalisetja Suloiset Sanan-lascut (Florinus 1987) sisältää yli 1500 suomenkielistä sananlaskua (Hautala 1954, 49). Florinus laati kokoelmansa 1600-luvun lopulla, jolloin luterilaisen uskon - ja näin ollen myös papiston - aseman vakiinnuttaminen Suomen alueella oli ajankohtaista. Papiston kiinnostusta suomenkielisiin sananlaskuihin saattoi lisätä se, että kansan käyttämät sananlaskut eivät olleet Raamatun sananlaskuja, mutta niiden olemassaolo korosti kansankielisen papiston tarvetta kansan valistajana. 1700-luvun ajatukset periaatteellisesta samanarvoisuudesta (säätyjen puitteissa) sopivat valistukseen. Valistuksen ajan aatemaailma edesauttoi näkemään kansan elämässä mielenkiintoisia ja hyödyllisiä taitoja, joista erityisesti sananlaskuja on pidetty kansan viisauden kiteytyminä.

Se, että Suomi irrotettiin Ruotsista ja siirrettiin osaksi Venäjää, vaikutti kansankielen asemaan. ${ }^{3}$ Papiston kieli ja asema riippui paljolti paikkakunnasta, samoin talonpoikaissääty oli sekä suomen- että ruotsinkielistä. Suurin osa autonomian ajan Suomen alueella asuneista ihmisistä oli suomenkielistä, omistamattomaan luokkaan kuulunutta rahvasta. ${ }^{4}$ Suomen autonominen asema osana Venäjää mahdollisti valtion tukeman sukukielien ja -kansojen perinteen tallentamisen ja tutkimuksen. Venäläistämismahdollisuus koettiin silti uhkana Suomessa, joten oman kielen aseman korostaminen oli keino tukea autonomista kansallista asemaa. Lönnrotin aloittama kansanrunouden ja sananlaskujen keruu oli yksi vastaus tähän Turun romantiikan kauden aloittamaan kansallistunteeseen ja sen tarpeeseen. Carl Axel Gottlund toteaa Otava eli suomalaisia huvituksia -teoksessaan tarkoituksena olleen "toteksi näyttää, Suomalaisia ennen olleen viisaampia ja enempi valistuneita kuin nykyisin (myö puhumma ainoastansa moa-rahvasta)" (Gottlund 1831, 22). Vuonna 1818 ilmestyneet Juteinin sananlaskukirja ja Gottlundin väitöskirjan liitteessä olleet sananlaskut ovat Florinuksen kokoelman jälkeen alallaan ajallisesti seuraava tiedossa olevia julkaistuja suomenkielisiä sananlaskukokoelmia.

3 Esimerkiksi 1.8.1863 annettiin Asetus Suomen kielen yhdenvertaisuudesta Ruotsin kielen kanssa suomalaista väestöä koskevissa asioissa. (SA).

4 Rahvaan kieli on pääasiallisesti ollut suomi, sillä vain noin kymmenesosa suomalaisesta rahvaasta on ollut ruotsinkielisiä (Niemi 1969, 55). 
Liisa Granbom-Herranen: Suomalaisen sananlaskututkimuksen aikakaudet

\section{SANANLASKUJEN KERUUN ERITYISYYS 1800-LUVULLA}

Vuoden 1827 Turun suurpalossa suurin osa Turun Akatemiassa säilytetyistä julkaisuista ja käsikirjoituksista tuhoutui. Tuhoutuneiden kirjoitusten joukossa oli pääosa siihen mennessä kerätystä sananlaskuaineistosta. 1800-luvun suomenkielisten sananlaskujen tunnetuin kerääjä oli Lönnrot. Hänen kirjasi sananlaskuja etenkin vuosina 1835-1837 tekemillään runonkeruumatkoillaan. Näistä muistiinpanoista ja muiden keräyksistä sekä ennen julkaistuista sananlaskuista Lönnrot toimitti vuonna 1842 ilmestyneen Suomen Kansan Sananlaskuja-teoksen, joka on kuitenkin jo valikoitua aineistoa. Lönnrotin keräykset loivat perustaa Suomalaisen Kirjallisuuden Seuran kansanrunousarkiston sananlaskukortiston perustamiselle. (Apo ym. 1998, 18.)

1800-luvun puoliväli oli Suomen poliittisessa historiassa muutoksien aikakautta. Lainsäädäntö muuttui samalla kun sekä taloudellinen että sosiaalinen elämä kokivat muutoksia. (Waris 1974 , 9.) Suomen sotilasstrateginen asema oli merkittävä siitä huolimatta, ettei autonomian aikana Suomen suuriruhtinaskunnassa sodittu. Rauhan aika mahdollisti kerääjien varsin esteettömän liikkumisen Suomen suuriruhtinaanmaan alueella. Talouselämän kehittymisen ja taloudellisen vakauden lisääntymisen myötä teollisuuden asema alkoi vakiintua ja laajeta vaikuttaen maaseudun ammattirakenteen muuttumiseen. Muita liikkumisen ja siten keräämisen mahdollistaneita muutoksia olivat maan sisäisten kulkuyhteyksien eli rautateiden, maanteiden ja vesireittien kehittyminen. Maaseudulla palkkaussäännön muutos edesauttoi vapaata liikkumista maassa.5 1800-luvun puolivälissä alkoi suomenkielisten sananlaskujen tallentaminen kiinnostaa papiston lisäksi uusia ryhmiä, joita olivat suomenkielisyydestä kiinnostuneet opiskelijat ja tutkijat. Vuonna 1831 perustetun Suomalaisen Kirjallisuuden Seuran kansanrunousarkiston kerääjäverkoston perusta oli kansallismielisten ylioppilaiden aloittama keruu 1800-luvulla. (Ilomäki 1998, 148.) Papiston merkitys sananlaskujen tallentajina väheni. Suomenkielisissä saarnateksteissä sananlaskuilla oli silti edelleen kiistämätön sijansa osana luterilaista jumalanpalvelusta.

Monet eri alojen edustajat ovat oman työnsä ohella kartuttaneet sananlaskukokoelmia, vaikka sananlaskujen keruu ei ollutkaan heidän ensisijainen tehtävänsä. Suomalaisen paremiografian erityispiirteenä on 1800-luvulta lähtien ollut sen yhteys sekä lähetystyöhön että tutkimusmatkailuun. Lähetystyössä saarnaajat keräsivät työnsä ohessa myös sananlaskuaineistoa, samoin kuin kielitieteilijät ja sotilastoimissa tiedustelijat tutkimusmatkoillaan. (Vesterinen 2003.) Lähetystyöhön kiinteässä yhteydessä olleen sananlaskujen keräyksen aloitti Martti Rautanen 1800-luvulla. Vuosina 1930-32 sananlaskujen keräystä Ovambomaalla organisoi Suomen Tiedeakatemian toimeksiannosta 1900-luvun alussa lähetyssaarnajana toiminut Emil Liljeblad (Kuusi 1970, 6-7, 11). 1900-luvun alussa sosiaaliantropologi Edward Westermarck keräsi runsaasti sananlaskuja tutkimusmatkoillaan (Stroup 1982). Lähetystyön oikeutus tai velvoite perusteltiin kohdemaan epäkristillisen ja sen perusteella kehittymättömänä pidetyn moraalin kautta, joka ajateltiin voitavan osoittaa kansan käyttämässä sananlaskuperinteessä. Pyrkimys

5 30.1.1865 Palkkaussääntö isännille ja palkollisille (SA). 
liittää suomalainen tutkimus eurooppalaiseen tiedeyhteistyöhön ja halu kiinnittyä länteen lisäsivät kiinnostusta eurooppalaisiin siirtomaihin suuntautuneeseen tieteellisesti motivoituneeseen tutkimusmatkailuun.

1800-luvun lopulla ja 1900-luvun alussa Euroopassa vaikutti uusi romanttinen virtaus, joka korvasi realismin ja naturalismin aatteita. Suomessa tämä sai kansallisromanttisen luonteen. Sananlaskujen kiinnostavuuteen vaikutti itsenäistymisen myötä uudenlainen kansallistunne ja nationalismi. Poliittinen fennomania vaikutti Suomessa 1920- ja 1930-luvuilla (Lassila 2003, 10). Suomen "luonnollisten rajojen" katsottiin sisältävän myös sukukielien asuttamat alueet. Akateemisten kansallismielisten miesten toiminnan tavoitteeksi tuli kieliperheen yhdistäminen. (Wilson 1978, 63.) Tämä oli myös sananlaskujen keräysten aikakautta, jolloin Suomalaisen Kirjallisuuden Seura organisoi kerääjäverkoston vuonna 1934, ja lehtiin lähetettiin teemakyselyitä 1920- ja 1930-luvuilla. Myös yliopistojen osakunnat toimeenpanivat 1930-luvulla sananlaskukeräyksiä. ${ }^{6}$ Osakuntien kerääjät olivat ylioppilaita, jotka mitä ilmeisimmin ovat edustaneet pääsääntöisesti ryhmää, johon Ilomäen märitttelemät 1800- ja 1900-lukujen vaihteen kansanperinteen kerääjät kuuluivat" [...] nuoria miehiä, älymystön lapsia, jotka kulkivat etsimässä kalevalaista aitoa runoutta" (Ilomäki 1998, 148). Kuten sata vuotta aiemmin, kyse oli kenties pienen kansakunnan olemassaolon oikeutuksen todentamisesta. Tarvittiin suomalaisuutta, omaa historiaa ja omaa perinnettä. Elettiin isänmaallisten liikkeiden aikaa.

Kaikkina aikoina ovat yhteiskunnallisen muutoksen vaikuttajat hyödyntäneet opetusta ja kasvatusta muutoksen aikaansaamiseksi. Helsingin yliopiston suomen kielen professori Karl August Engelbrekt Ahlqvistin vuonna 1869 toimittama sananlaskukokoelma Valittuja Suomen Kansan Sananlaskuja Nuorisoa varten Sana- ja asiaselitysten kanssa sisältää sananlaskuja varustettuina selityksin. Ahlqvistin mukaan selitykset tarvitaan, koska aika on uusi ja "ett'ei nuoriso, varsinkin kaupungeissa ja herrassäädyissä syntynyt, voi selittämättä ymmärtää kaikkia sananlaskujamme, kuin niissä on monessakin osoituksia rahvaan elämänlaatuun, tapoihin ja askareihin, jotka rahvaasta kauempana kasvaneelle eivät voi olla muuta kuin ymmärtämättömiä” (Ahlqvist 1929, 4). Myös Florinus ilmoittaa teoksensa esipuheessa julkaisseensa kokoelman sananlaskujen hyödyllisen opettavuuden takia ja vetoaa muun muassa Salomon sananlaskuihin (Hautala 1954, 50). Ei siis ihme, että Suomessakin kieli, kansakoulu ja sananlaskut liitetään sekä kansallisromanttiseen toimintaan että itsenäisyyden suureen kertomukseen. Kansallisromanttisen ajattelun mukaan sananlaskujen oikea elämä oli maaseudulla, kuten kasvatusympäristön ihanteena oli maalaisidylli. Sananlaskuilla on ollut sijansa jumalanpalveluksissa ja saarnojen yhteydessä toteutuneessa kansanopetuksessa jo aikana, jolloin lukutaito ei ollut yleistä (Heikkinen 1989, 61, 92). Sananlaskut sopivat jo muotonsa puolesta käytettäväksi kansanopetuksessa, säilyväthän sananlaskut esimerkiksi rytminsä vuoksi hyvin muistissa.

6 Keräyksistä julkaistiin maakunnittain sananlaskukokoelmia, ks. GranbomHerranen 2008, 79. 
Liisa Granbom-Herranen: Suomalaisen sananlaskututkimuksen aikakaudet

\section{SUOMENKIELISTEN SANANLASKUJEN TUTKIMUKSEN ALKU}

Sananlaskujen tutkimus alkoi Suomessa huomattavasti myöhemmin kuin niiden muistiin merkitseminen ja keruutyö (Liite 1). Suomalainen sananlaskututkimus noudattelee monin osin suomalaisen kansanrunouden tutkimuksen yleisiä suuntauksia, joita Jaakko Hautala on käsitellyt vuonna 1954 julkaistussa teoksessaan Suomalainen kansanrunoudentutkimus. Tutkimus on aina aikakauteen sidottua eikä se siten voi olla yhteiskunnallisesti neutraalia. Varsin henkilökohtaisillakin valinnoilla ohjautuneen tulosten tarkastelun vaikutus kumuloituu myöhempien tutkijoiden tukeutuessa olemassa olevaan tutkimukseen eikä edes tutkijayhteisön yksimielisyys takaa tiedon totuutta. (Niiniluoto 1994, 41; Granbom-Herranen 2008, 87.) Pienen kansan parissa henkilökohtaisilla ystävyyssuhteilla ja sukulaisuudella on merkitystä. Suomalainen folkloristiikka ja siihen kuuluen sananlaskujen tutkimus on ollut tällainen yhdistävä tekijä, aina Turun Akatemian ajoista tähän päivään asti (Hautala 1954, Lassila 2003).

Kansallisuusaatteen ja kansanrunouden tutkimuksen yhteys on Suomessa jäänyt toteavan tarkastelun tasolle. Aatteellis-poliittisena ilmiönä siihen on paneutunut yhdysvaltalainen folkloristi William Wilson väitöskirjassaan vuonna 1978. Vaikka kaikki Wilsonin esittämät väitteet eivät saaneet suomalaisen tiedeyhteisön varauksetonta hyväksyntää, se toi esille tarpeen keskustella politiikan ja folkloristiikan yhteydestä. (Honko 1979, 149.) Tätä keskustelua ei kuitenkaan juuri käyty. Yllättävää on suomalaisen sananlaskututkimuksen vahva sitoutuminen nationalismiin. Kansallisaatteen voidaan miltei ajatella olevan niin itsestään selvää, että keskustelu on turhaa, mutta vaietuista itsestäänselvyyksistä tulee helposti hyväksyttyjä. Aivan kuin perinteen arvo kyseenalaistuisi, jos tutkimus osoittaa siinä olevan jotain ristiriitaista tai ei-toivottua. Lauri Honko (1979) on ainoa asiaa vähänkään kriittisin äänenpainoin käsitellyt suomalainen tutkija. Kritiikittömyys tuskin miellyttää sen enempää sananlaskuista harrastuneisuuttaan kiinnostuneita ihmisiä kuin niiden tutkimukseen paneutuvia paremiologejakaan. Jos sananlaskuja vain rakastetaan kokien ne muuttumattomiksi ja jos niiden tutkimus asettuu arvioinnin tavoittamattomiin, ei sananlaskuilla ole elinmahdollisuutta muualla kuin nationalistisessa kielenkäytössä. Minkään aikakauden perinne ei sinänsä muutu, vaan perinteeseen suhtautuminen vaihtelee tarkasteluajankohdasta riippuen.

Ensimmäinen suomenkielisiä sananlaskuja käsittelevä väitöskirja on latinankielinen, Upsalassa vuonna 1818 julkaistu Carl Axel Gottlundin De proverbiis Fennicis (Liite 1). Kielitieteisiin kuuluva väitöskirja ansaitsee tulla mainituksi ensimmäisenä suomenkielisiä sananlaskuja käsittelevänä paremiologisena opinnäytteenä. Suomessa sananlaskujen kansainvälisesti arvostettu tutkimus on pitkälti perustunut Julius Krohnin (1835-1888) alun perin paikkakunnallis-historialliseksi menetelmäksi nimittämään sekä Kaarle Krohnin (1863-1933) täydentämään maantieteellis-historialliseen menetelmään. Sen perusta on Charles Darwinin evoluutioteoriassa. Lähtökohta on ymmärrettävä, kun muistamme, että Julius Krohn aloitti yliopisto-opintonsa luonnontieteiden parissa (Lassila 2003,36). Tämän myös suomalaiseksi menetelmäksi kutsutun tarkastelun tavoitteena on selvittää, millaisten vaiheiden kautta nykyinen sananlaskusto on eriytynyt eli mitä sananlaskuja on ollut mihinkin aikaan missäkin ja mistä ne ovat sinne tulleet. Tätä kautta olisi mahdol- 
lista löytää sananlaskujen kantamuodot. Menetelmä on edesauttanut perinnearkistojen syntyä ja kehittymistä 1800-luvulta alkaen. Maantieteellis-historiallinen menetelmä antoi tieteellisen perustan paremiologialle sekä sananlaskukokoelmien systematisoinnille. Kokoelmat puolestaan ovat tarjonneet mahdollisuuden suomalaisen sananlaskututkimuksen kehittymiselle. (Granbom-Herranen 2008, 78.) Krohnin oppilaista A. A. Koskenjaakko julkaisi vuonna 1913 väitöskirjan Sananlaskututkimuksia I. Laki, oikeus ja oikeudenkäynti suomalaisissa sananlaskuissa (Liite 1). Paremiologiassa suomalaisella menetelmällä on ollut, ja on edelleen, kansainvälistä merkittävyyttä. Yhtenä tunnetuimmista Krohnien seuraajista 1900-luvulla mainittakoon folkloristi ja paremiologi Archer Taylor (1890-1973) (Hautala 1954, 276; Honko 1979, 145). Muun muassa Taylorin vuonna 1931 julkaistu määritelmä sananlaskusta on edelleen käyttökelpoinen ja siihen tukeutuvat monet uusimmatkin määritelmät (Taylor 1994; Mieder 2004).

\section{SANANLASKUTUTKIMUS FOLKLORISTIIKAN OSANA}

Väitöskirjassaan vuodelta 1950 Matti Kuusi käytti typologiseksi analyysiksi nimittämäänsä tutkimusmenetelmää tutkiessaan Sampo-eeposta (Kuusi 1949). Sananlaskuihin sovellettu typologinen analyysi on edelleen käytössä muokattuna ja sovitettuna tietokonepohjaiseen sananlaskutietokantaan (Lauhakangas 2001). Sananlaskututkimuksen parissa Kuusi aloitti 1950-luvulla, jolloin Suomessa elettiin jälleenrakentamisen aikaa. Kansallisesti tärkeää oli tuolloin osoittaa suomalaisuudella olevan ikiaikaiset juuret. Tämän aikakauden suomalaiselle yhtenäisyydelle oli merkittävää muun muassa Helsingin olympialaiset, sotakorvauksien maksu sekä Hangon ja Porkkalan alueiden palautuminen Suomelle. 1950-luvulla, maailmansotien jälkeisessä uudessa kansallisen identiteetin etsintävaiheessa kansaluonnetta ja sen määrittelyä tarvittiin Suomen erityisaseman osoittamiseksi. Artikkelissa Sananparsien suosionmuutoksista (1953) Kuusi tarkastelee sananparsia nimenomaan kansanluonteen kuvaajina. Yleistävää teemaa Kuusi jatkaa myöhemminkin esimerkiksi vertaillessaan käsityksistä naisten asemasta Afrikassa ja Suomessa perustellen näkemyksiään afrikkalaisilla ja suomalaisilla sananlaskuilla (Kuusi 1971) sekä yhdistäessään sananlaskujen muutokset asennemuutoksiin (esim. Kuusi 1988). Kuusi etsi kansanpsykologisten syysuhteiden näkymistä sananparsissa.

Kuusta voidaan pitää evolutionistina. Häntä ja Martti Haaviota on pidetty viimeisinä suomalaisina maantieteellis-historiallisen menetelmän edustajina (Honko 1979, 146). Maantieteellis-historiallisen menetelmän ja typologisen näkökulman painottuminen olivat vaikuttavina piirteinä suomalaisessa folkloristiikan parissa tehdyissä sananlaskuja käsittelevissä opinnäytteissä Kuusen professuurin aikana. Sananlaskututkimus keskittyi Kuusen ohjauksessa 1950- ja 1960-luvuilla Helsingin yliopiston suomalaisen ja vertailevan kansanrunoudentutkimuksen oppiaineeseen. Kiinnostuksen kohteena olivat tuolloin sananlaskujen maantieteellis-historiallinen selvitys, sananlaskut ja niiden esiintymistiheys, sananlaskut ja niiden erilaiset toisinnot, alueelliset vertailut, sananlaskun syntyaika, sen kulkeutuminen paikkakunnalta toiselle ja erilaiset vertailut myös kansainvälisten lainojen tutkimuksena. (Liite 1.) 1950- ja 1960-lukujen suomalainen 
sananlaskututkimus noudatti yleistä kansanrunoudentutkimuksen suuntaa analyysiin pyrkivine tutkimusotteineen. Tähän aikakauteen sijoittuu peräti 11 sananlaskuja käsittelevää pro gradu -tutkielmaa ja kolme lisensiaatintyötä. Väitöskirjoja julkaistiin kaksi, Iris Järviö-Niemisen Suomalaiset sanomukset vuodelta 1959 käsittelee sanomuksia ja Pentti Leinon Strukturaalinen alkusointu suomessa folklorepohjainen tilastoanalyysi vuodelta 1970. (Liite 1.)

1970-luvun alussa, kenties 1960-luvun radikalismin vaikutuksesta, kansanrunouden tutkimus laajeni uusille alueille kuten poploreen ja lasten perinteeseen. Sananlaskut saivat sijansa niissäkin. Kyseessä saattoi olla palautusilmiö eli yhteiskunnallinen tarve modernin liittämisestä osaksi sukupolvien perinnettä. Sananlaskuihin liittyviä opinnäytteitä ei tältä ajalta ole, syynä saattaa olla sananlaskututkimuksessa vaikuttaneiden kartoittavien ja analyysiin pyrkivien käytänteiden yhteensopimattomuus uusien folklorististen kiinnostusten kohteiden kanssa. 1980- ja 1990-luvuilla kognitiivinen tutkimusote valtasi alaa myös suomalaisen paremiologian parissa. Sananlaskututkimuksessa alkoi uusi aikakausi, jonka voidaan katsoa kestäneen 1990- ja 2000-lukujen taitteeseen. Kuusen oppilaat käsittelivät sananlaskuja 1980-luvulla kolmessa pro gradu -tutkielmassa sekä kolmessa lisensiaatintyössä. Vuonna 1986 ilmestyi Pekka Hakamiehen väitöskirja Venäläisten sananparsien vaikutus karjalaiseen ja suomalaiseen sananparsistoon. (Liite 1.)

1990-luvulta alkaen folkloristiikassa on haettu uusia yhteyksiä sananlaskuille. Väitöskirjoja ei kuitenkaan folkloristisesta sananlaskututkimuksesta julkaistu ja pro gradu -tutkielmiakin tehtiin vain kaksi. 1990-luvulta lähtien sananlaskut ovat olleet usean tieteenalan tutkimusten kohteena. Suomalaisia sananlaskuja käsitteleviä opinnäytetöitä on tehty kielitieteissä, taloustieteessä, kasvatustieteissä, kirjallisuuden tutkimuksessa, yhteiskuntatieteissä ja teologiassa. Yhteisyys folkloristiikkaan löytyy siitä, että näissäkin tutkimuksissa käsiteltyjen sananlaskujen suomenkielisen käytön alkuperä on suullisessa kansanperinteessä. Sananlaskuja käyttävässä tutkimuksessa näkökulma on sidoksissa lähtökohtana olevaan tutkimusongelmaan, esimerkiksi sananlaskujen käyttöön psykologisissa testeissä. Tämä ei ole sananlaskututkimusta sinänsä. (Granbom-Herranen 2010b, 216).

Merkittävin suomalainen sananlaskututkija ja sananlaskututkimukselle suunnanantaja 1900-luvun puolivälistä vuosisadan loppuun on ollut Matti Kuusi. Hän ei itse toiminut kenttätöissä, vaan hänen käyttämänsä aineistot ovat pääasiassa kilpakeräyksiä tai poimintoja aikaisemmista julkaisuista. Monessa tapauksessa aineistot ovat olleet käännöksiä. Hänen johtopäätöksiään arvostetaan edelleen ja niille on annettu autoritaarinen asema, joten uusikin sananlaskuihin liittyvä tutkimus tukeutuu edelleen varsin kritiikittömästi Kuusen tulkintoihin. (Granbom-Herranen 2008, 80.) Kuusi oli varsin tuottoisa kirjoittaja ja hänen kiinnostuksensa kohteena olivat usein nimenomaan sananlaskut. Kuusen sananlaskuja koskevan tuotannon tarkastelussa haasteena on erottaa tieteelliseksi tarkoitettu ja popularisoitu tieto toisistaan. Suomalaisen Kirjallisuuden Seuralla on käynnissä viisivuotinen tutkimushanke Kuusen elämäkerrasta. Hankkeen keskeisiä tavoitteita ovat Kuusen elämäntyön temaattisten ja ideologisten päälinjojen hahmottaminen aikansa kontekstissa. (SKS hanke 2008.)

2000-luvulla on valmistunut yksi folkloristiikan alaan kuuluva sananlaskuja käsittelevä väitöskirja, Eija Starkin Köyhyyden perintö: Tutkimus kulttuurisen tiedon sisällöistä ja 
jatkuvuuksista suomalaisissa elämäkerta-ja sananlaskuaineistoissa (2011), sekä neljä pro gradu -tutkielmaa. 2000-luvulla on julkaistu kaksi paremiologiaan sijoittuvaa, keskenään eri näkökulmaista sananlaskuja käsittelevää väitöskirjaa: Outi Lauhakankaan sosiaalipsykologiaan kuuluva Pubeesta ihminen tunnetaan. Sananlaskujen funktiot sosiaalisessa vuorovaikutuksessa (2004) ja oma kasvatustieteen väitöskirjani Sananlaskut kasvatuspuheessa - perinnettä, kasvatusta, indoktrinaatiota? (2008). (Liite 1.)

Suomalaisessa tutkimuksessa sananlaskujen tarkastelu niiden omassa elinympäristössään on toistaiseksi jäänyt vähälle huomiolle toisin kuin monessa muussa maassa tehdyssä kulttuuriantropologisesti suuntautuneessa tutkimuksessa. Tietoja perinteen esittäjistä tai esityskontekstista ei Suomessa ole systemaattisesti kerätty. Tähän on vaikuttanut suomalaisen tutkimustradition keruu- ja arkistointikäytännöt, joissa on painottunut pyrkimys Kalevalan lähdepohjan laajentamiseen sekä toisintojen keruu maantieteellishistoriallisen menetelmän mukaisesti. (Tarkka 2005, 11.) Sananlaskujen käyttö, käyttäjät ja käyttöyhteys ovat unohtuneet keskityttäessä ensisijaisesti kerääjien ja tutkijoiden tarpeisiin ja näkemyksiin luoda maantieteelliseen ja ajalliseen paikantamiseen sidottu kokonaiskuva. Sananlaskuista on haettu myös filosofisia tai runollisia kuvauksia sekä keskusteltu ryhmäominaisuuksista, kuten kansanluonteesta. Pääasiallinen kiinnostuksen kohde on ollut sananlaskujen rakenne, ja sananlaskuja on vertailtu keskenään niin historiallisina kuin paikallisina perinnetuotteina. Suomalaisessa sananlaskututkimuksessa on ensisijaisesti pohdittu kielellistä kulttuurien tulkinnan problematiikkaa (Lauhakangas 2004, 69). Nyt suomalainen sananlaskututkimus on siirtymässä uuteen aikaan, kun maantieteellis-historiallinen menetelmä on asettunut kognitiivisten, kontekstuaalisten ja funktionaalisten lähestymistapojen rinnalle. Maantieteellis-historiallinen menetelmä on kuitenkin edelleen paremiologiassa käytössä oleva menetelmä.

Murroskaudet ovat osaltaan aiheuttaneet kansallisten asioiden esille tuomisen. $\mathrm{Ne}$ ovat myös toimineet pontimena koota ja tutkia sananlaskuja. Kansanrunoudentutkimus on tieteenalana herättänyt pitkään aktiivisesti toimineiden kansallisaatteen kannattajien kiinnostusta. Esimerkiksi Martti Haavio ja Matti Kuusi osallistuivat ainakin Akateemisessa Karjalaseurassa toimintaan, jolla pyrittiin vahvistamaan suomalais-ugrilaisten asemaa, identiteettiä ja keskinäistä yhteenkuuluvuutta. He olivat mukana rakentamassa Suur-Suomea. (Wilson 1978, 170.) Nationalismin vaikutus ei rajoitu vain perinteenkeruun innoittajan rooliin, sillä oli vaikutusta aineiston valikoitumiseen. Kansallismielisillä aatteilla on ollut suora yhteys tutkimukseen, oppituolin haltijoihin ja siten myös tutkimusresurssien käytön ohjautumiseen.

\section{SUHTAUTUMINEN SANANLASKUIHIN JA KANSALLISUUSAATTEET AJAN ILMIÖINÄ}

Kiinnostus suomalaisiin sananlaskuihin liittyy yhteiskunnallisten murroksen aikaan. Kriisien aikana sananlaskut puhuttavat. Sananlaskut ovat yhteisön eletyn historian tuottamia ilmaisuja, ne kertovat ainoastaan jonkin ilmiön olemassaolosta kyseisenä aikana. Sananlaskut eivät selitä mitään ilmiötä tai perustele ilmiön olemassa oloa. 
Murrosjaksojen painottuminen sananlaskujen keruun, julkaisemisen ja tutkimuksen yhteydessä ei kuitenkaan kerro varsinaisesta sananlaskujen käytön yleisyydestä juuri näinä aikoina. Kunkin sananlaskujen tallentajan ja tutkijan kohdalla on hyvä kysyä, mitä tapahtui maassamme kulloisenakin aikakautena. Se, että kaksi tai useampi asia ovat samanaikaisia tai peräkkäisiä ei välttämättä rakenna niiden välille syy-seuraus -yhteyttä. Sananlaskujen arvottaminen voi olla tutkijan henkilökohtainen tai hänen aikakautensa edustama näkemys. Usko sananlaskujen erityiseen arvokkuuteen lienee osittain seurausta eri aikakausina uudistuvasta suomalaisuuden itseisarvoisesta korostumisesta. Tämä ikiaikainen suomalainen viisauden käsitys elää arjen puheessa edelleen.

Voitaneen ajatella, että 2000-luvun suomalaisuus Euroopan Unionissa on myös suomalaisuuden kriisi. Pienten kansojen aseman koetaan tarvitsevan tukea omasta menneisyydestään, varhaisempien aikojen kansasta. Tähän viittaavat Outi Lauhakankaan (2001) 1950-luvulle palautuva tyyppianalyysiin perustuvan luokituksen saattaminen tietokannaksi. Lähetystyön ja sananlaskujen keruun yhdistämistä sekä sananlaskujen popularisointia jatkoi 1980-luvulla Raimo Harjula (2000). Liisa Keltikangas-Järvisen (2000) 1800-luvun kansanluonnetta sananlaskuista kaipaileva asenne vetoaa sananlaskujen ja kansan nostalgisiin yhteyksiin. Viimeisimpään EU:n murroksen tuottamaan ajanjaksoon liittyy myös Sirkka Hirsjärven ja Leena Laurisen (2004) kasvatuksellisesti suuntautunut kiinnostus sananlaskuihin uskomuksina.

Nationalismiin kuuluu positiivisena piirteenä ylpeys omasta taustasta. Negatiiviseksi ilmiöksi nationalismi muuttuu, kun se toimii muiden kansojen tai oman maan vähemmistöjä halventaen. Suomessa lähes luku- ja kirjoitustaidottoman kansan käyttämä kieli nostettiin sananlaskuissa esille ja arvokkaaseen asemaan merkityksellisenä menneisyyden kuvaajana. Ensin tämän teki auttavasti suomentaitoinen papisto Ruotsissa ja sitten ruotsinkielinen sivistyneistö Venäjällä. Kolmannen kerran suomenkielinen perinne koki arvostusta, kun suomenkielisyyteen siirtymässä ollut kansallismielisten ryhmä haki yhteisyyttä sukukansojen kesken. Tällöin valtakunnan rajat haluttiin saattaa kielen ja perinteen mukaisiksi. Sananlaskut olivat toimineet eräänlaisena perusteluna suomen kielen oikeutukselle ruotsin kielen rinnalla 1600- ja 1700-luvuilla, 1800-luvulla niistä tuli arvokasta perinnettä ja 1900-luvulla ne saivat kansanviisauden statuksen. Nyt, 2000-luvun alussa, on kenties nousemassa esille uusi tarve kansallisen viisauden esille tuontiin ja sen arviointiin - rakenteiden muutoshan on taas voimakkaasti käynnissä. Maaseudun ja kaupungin elämäntapoja sovitetaan yhteen.

Kalevalan nousemista tai sen nostattamista suomalaisuuden kuvaksi voidaan pitää yhtenä syynä sille, että perinnelajina sananlaskut saivat myös Suomessa sakraalisen leiman (ks. esim. Mieder 1993, 36). Suomessa Raamatun ja Kalevalan sananlaskuilla on ylemmän auktoriteetin asema. Suomenkieliset sananlaskut ovat olleet kyseenalaistamattomia totuuksia ja muodoltaan muuttumattomia. Niistä tärkeimmät on löydettävissä Kalevalasta ja toiseksi tärkeimmät ovat Raamatusta. Mutta ovatko ne olleet erityisen pyhiä käytössä, suomenkielisen rahvaan parissa ennen toista maailmansotaa? Kalevala ja sen sankarit yhdistyvät runomittaan, kalevalaiseen muinaisuuteen. Kalevalamitasta tuli myös aitojen ja alkuperäisten - "niiden oikeiden" - sananlaskujen tunnus. Tunnetuin lienee "Sitä kuusta kuuleminen, jonka juurella asunto", joka liitettiin vuonna 1917 siemenestä kasvatetun ja vuonna 1931 Helsinkiin istutetun Itsenäisyyden kuusen muistolaattaan. 
Näillä kansallisuusaatteilla on varsin kauaskantoiset ja kulttuurissa laaja-alaiset vaikutukset. Varhaisemman tutkimuksen ja tutkimusperinteen kriittinen tarkastelu on aiemman tutkimuksen ja aikaisempien tutkijoiden arvostamista. Tavoitteena on uusien näkökulmien mahdollistuminen ja jo tuotetun tiedon tarkastelu tästä näkökulmasta käsin. Uudistuneessa eurooppalaisuudessa ovat myös sekä suomalainen paremiografia että paremiologia tulleet kansainvälistymisen myötä jälleen kerran ajankohtaisiksi.

\section{LÄHTEET}

\section{Kirjallisuus}

AGRICOLA, MIKAEL 1554: Rucouskiria Bibliasta. <https://www.doria.fi/handle/10024/43445> [luettu 27.9.2012].

AHLQVIST, A. 1929: Esipuhe "Valittuihin sananlaskuihin". - Koskimies, V.A. (toim.) Valikoima suomalaisia sananlaskuja. A. Ablqvistin mukaan [1869]. Helsinki: SKS. APO, SATU \& NENOLA, AILI \& STARK-AROLA, LAURA 1998: Introduction. Apo, Satu \& Nenola, Aili \& Stark-Arola, Laura (eds) Gender and folklore. Helsinki: SKS.

DORSON, RICHARD M. 1963: Current folklore theories. - Current Anthropology $4(1)$.

FLORINUS, HENRIK 1987 [1702]: Sananlaskut. Helsinki: SKS.

GOTTLUND, CARL AXEL 1831: Otava, eli Suomalaisia huvituksia. Osa 1. Tukholma: M. G. Lundbergin Kirjapaja.

GRANBOM-HERRANEN, LIISA 2008: Sananlaskut kasvatuspuheessa-perinnettä, kasvatusta, indoktrinaatiota? Jyväskylän yliopisto.

GRANBOM-HERRANEN, LIISA 2010a: Women's place in Finnish proverbs from childhood. - Folklore: Electronic Journal of Folklore 46.

GRANBOM-HERRANEN, LIISA 2010b: Is a proverb always a proverb? - Soares, Rui \& Lauhakangas, Outi (toim.) $3^{\text {rd }}$ Interdisciplinary Colloquium on Proverbs, Proceedings. Tavira: International Association of Proverbs.

GRANBOM-HERRANEN, LIISA 2011: Proverb - a literal phrase and a part of everyday speech. - Pamies, Antonio \& Luque Durán, Juan de Dios \& Fernández Martín, Patricia (eds) Paremiología y herencia cultural. Granada: Granada Lingvistica/ Educatori.

GRZYBEK, PETER 1987: Foundations of semiotic proverb study. Proverbium. 4.

HARJULA, RAIMO 2000: Parempi pakaroitta kuin päätä vailla. 500 itäafrikkalaista sananlaskua hyvästä elämästä. Helsinki: Yliopistopaino.

HARRIS-LOPEZ, TRUDIER 2003: Genre. - Feintuch, Burt (eds) Eight words for the study of expressive culture. Urbana and Chicago: University of Illinois Press.

HAUTALA, JAAKKO 1954: Suomalainen kansanrunouden tutkimus. Helsinki: SKS HEIKKINEN, ANTERO 1989: Perinneyhteisöstä kansalaisyhteiskuntaa. Helsinki: Yliopistopaino.

HIRSJÄRVI, SIRKKA \& LAURINEN, LEENA 2004: Lempeästi mutta lujasti. Suo- 
Liisa Granbom-Herranen: Suomalaisen sananlaskututkimuksen aikakaudet

malaisia sanontoja ja arkiuskomuksia kasvatuksesta. Helsinki: WSOY.

HONKO, LAURI 1979: A hundred years of Finnish folklore research. - Folklore 90(2). HONKO, LAURI 1998: Folklooriprotsess. - Mäetagused 6.

ILOMÄKI, HENNI 1998. The image of women in Ingrian wedding poetry. - Apo, Satu \& Nenola, Aili \& Stark-Arola, Laura (eds) Gender and folklore. Helsinki: SKS. JOKINEN, EEVA 2005. Aikuisten arki. Helsinki: Gaudeamus.

KELTIKANGAS-JÄRVINEN, LIISA 2000: Tunne itsesi, suomalainen. Helsinki: WSOY

KUUSI, MATTI 1949: Sampo-eepos: typologinen analyysi. Helsinki: Suomalais-ugrilainen seura.

KUUSI, MATTI 1953: Sananparsien suosionmuutoksista. - Virittäjä 57.

KUUSI, MATTI (toim.) 1970: Ovambo proverbs with African parallels. Helsinki: SKS.

KUUSI, MATTI 1971: Naisen arvo Suomen ja Ambomaan sananlaskustossa. Helsinki: Suomalainen tiedeakatemia.

KUUSI, MATTI 1988: Lukijalle. - Kuusi, Matti (toim.) Rapatessa roiskuu. Nykysuomen sananparsikirja. Helsinki: SKS.

KUUSI, MATTI (toim.) 1990 [1953]: Vanhan kansan sananlaskuviisaus. Suomalaisia elämänohjeita, kansanaforismeja, lentäviä lauseita ja kokkapuheita vuosilta 1544-1826. Helsinki: WSOY.

LASSILA, PENTTI 2003: Ihanteiden isänmaa: Julius Krohnin romanttinen fennomania ja kirjallisuus. Helsinki: Yliopistopaino.

LAUHAKANGAS, OUTI 2001: The Matti Kuusi international type system of proverbs. Helsinki: SKS.

LAUHAKANGAS, OUTI 2004: Pubeesta ihminen tunnetaan. Sananlaskujen funktiot sosiaalisessa vuorovaikutuksessa. Helsinki: SKS.

LAUKKANEN, KARI \& HAKAMIES, PEKKA (toim.) 1997 [1978]: Sananlaskut. Helsinki: SKS.

LÖNNROT, ELIAS 1981 [1842]: Suomen Kansan Sananlaskuja. Espoo: Weilin \& Göös.

MIEDER, WOLFGANG 1993. Proverbs are never out of season. Oxford, New York: Oxford University Press.

MIEDER, WOLFGANG 2004: Proverbs. Westport, Connecticut, London: Greenwood Press.

NIEMI, ONNI 1969: Pohjakoulutuskysymys yhteiskunnallisena ongelmana Suomessa. I Autonomian aika. Turku: tekijä.

NIINILUOTO, ILKKA 1994: Tiede ja tieteenfilosofia. - Niskanen, V.A. (toim.) 1994. Tieteellisten menetelmien perusteita ihmistieteissä. Helsinki: Yliopistopaino.

NIRVI, R.E. \& HAKULINEN, LAURI (toim.) 1953 [1948]: Suomen kansan sananparsikirja. Porvoo: WSOY.

OBELKEVICH, JAMES 1994. Proverbs and social history. - Mieder, Wolfgang (ed.) Wise words. New York: Garland

PRAHLAD, SW. ANAND 1996. African-American proverbs in context. Jackson (MS): University Press of Missisippi.

SA = Suomen Suurirubtinaanmaan Asetuskokoelma 1860-1917. 
Liisa Granbom-Herranen: Suomalaisen sananlaskututkimuksen aikakaudet

SKS HANKE 2008: < http://www.finlit.fi/tutkimus/> [luettu 20.9.2012]

STROUP, TIMOTHY (ed.) 1982: Edward Westermarck: Essays on his life and works. Helsinki: Societas Philosophica Fennica.

TARKKA, LOTTE 2005. Rajarabvaan laulu. Helsinki: SKS.

TAYLOR, ARCHER 1994 [1962]: The wisdom of many and the wit of one. - Mieder, Wolfgang \& Dundes, Alan (eds). The wisdom of many. Essays on the proverb. New York, London: Garland Publishing Inc.

VESTERINEN, ILMARI 2003: Tieteen ja uskon matkamiehiä. - Kervanto-Nevanlinna, Anja \& Kolbe, Laura (toim.) Suomen kulttuurihistoria. Osa 3. Helsinki: Tammi.

WARIS, HEIKKI 1974: Muuttuva suomalainen yhteiskunta. Porvoo: WSOY.

WILSON, WILLIAM 1978: The Kalevala and Finnish politics. - Oinas, Felix J. (ed.) Folklore, nationalism, and politics. Columbus, Ohio: Slavica Publishers.

\section{Muut lähteet}

GRZYBEK, PETER 2011: Proverb variants and variations: a new old problem? Esitelmä " $5^{\text {th }}$ Interdisciplinary Colloquium on Proverbs"-konferenssissa.

HAUSER, STEFAN 2012: Diachrone Beobachtungen zur Phraseologie in der Sportberichterstattung der Tagespresse. Esitelmä "EUROPHRAS 2012"-konferenssissa.

MIKKOLA, KATI 2012: Finnish Literature Society and self-taught folklore collectors. Esitelmä "Archives and Communities"-konferenssissa 2012.

SCHMALE, GÜNTER 2012: Forms and functions of proverbs and proverbial expressions in authentic conversation. A Corpus-Based Study. Esitelmä "EUROPHRAS 2012"-konferenssissa.

Kasvatustieteen tohtori ja filosofian maisteri (folkloristiikka) Liisa GranbomHerranen toimii Suomen Akatemian tutkijatohtorina Jyväskylän yliopistossa kasvatustieteiden laitoksella. 
LIITE 1: Paremiologian ja paremiografian yhteys aikakausiin

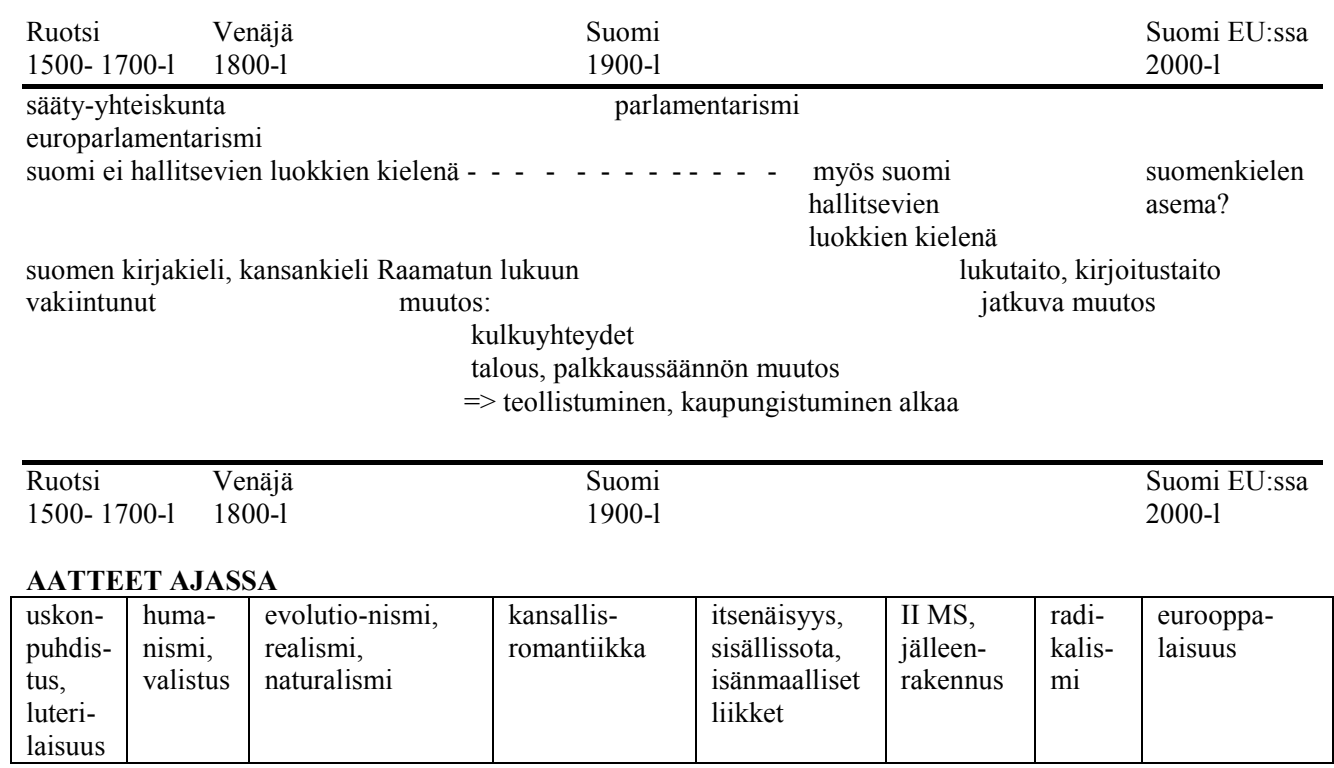

\section{PAREMIOGRAFIA}

\begin{tabular}{|c|c|c|c|}
\hline $\begin{array}{l}\text { papisto } \\
\text { Agricola, } \\
\text { Florinus }\end{array}$ & $\begin{array}{l}\text { kerääjät } \\
\text { Lönnrot }\end{array}$ & $\begin{array}{l}\text { kansankerääjät } \\
\text { SKS: keruukutsut, teemakyselyt }\end{array}$ & $\begin{array}{l}\text { Internet- } \\
\text { yhteisöt }\end{array}$ \\
\hline & & $\begin{array}{l}\text { lähetystö, } \\
\text { tutkimusmatkat }\end{array}$ & \\
\hline
\end{tabular}

\section{PAREMIOLOGIA}

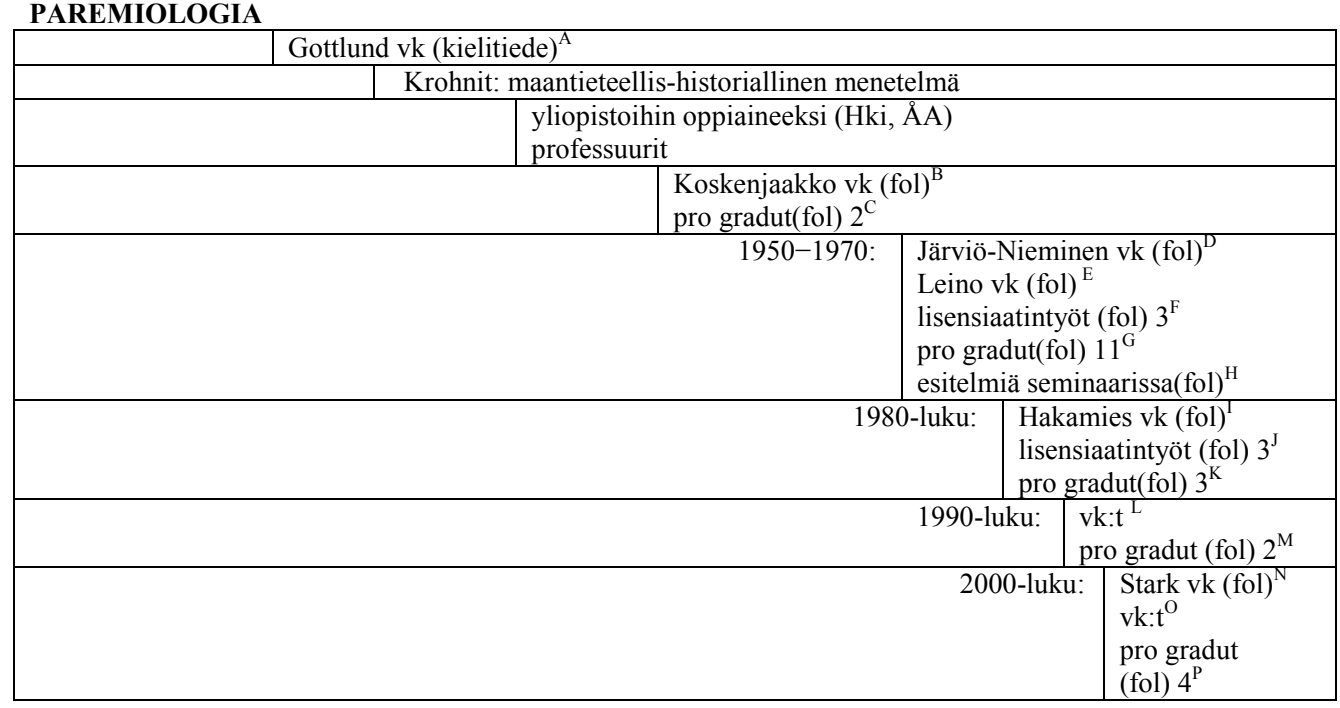




\title{
Liisa Granbom-Herranen: Suomalaisen sananlaskututkimuksen aikakaudet
}

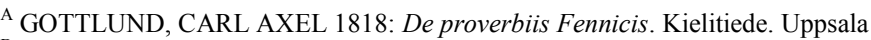 \\ ${ }^{\mathrm{B}}$ KOSKENJAAKKO, AA 1913: Sananlaskututkimuksia I. Laki, oikeus ja oikeudenkäynti suomalaisissa sananlaskuissa. \\ Helsinki: Suomalainen tiedeakatemia. \\ ${ }^{\mathrm{C}}$ Tutkielmissa ei ole vuosilukua. \\ Paalanen, Yrjö E. Hevonen suomalaisissa sananlaskuissa.. Fol. Hki. \\ Paloheimo, Anni. Lintuja käsittelevät sananlaskut Suomessa. Fol. Hki. \\ D JÄRVIÖ-NIEMINEN, IRIS 1959: Suomalaiset sanomukset. Helsinki: SKS. \\ E LEINO, PENTTI 1970: Strukturaalinen alkusointu suomessa folklorepohjainen tilastoanalyysi. Helsinki: SKS. \\ F Järviö, Iris 1957. Suomalaisista wellerismeistä. Fol. Hki. \\ Leino, Pentti 1965. Suomalaisen sananparren alkusointuisuudesta. Fol. Hki. \\ Kuusi, Anna-Leena 1970. Johdatusta fraasianalyysiin ja -systematiikkaan: havaintoja Aleksis Kiven tyylilajeista ja \\ kansankielen fraasityypeistä. Fol. Hki. \\ ${ }^{\mathrm{G}}$ Vartiainen, Anja 1953. Huomioita suomalaisista riimisananparsista. Fol. Hki. \\ Järviö, Iris 1954. Suomalaisista wellerismeistä. Fol. Hki.
}

Partanen, Laila 1958. Matthias Akianderin sanaparsikäsikirjoitukset. Fol. Hki.

Marjanen, Kaarina 1962. Mustalaiswellerismit. Fol. Hki.

Lehtonen, Pirkko 1963. Proverbial comparisons and similies in some novels by Sir Walter Scott. Fol. Hki.

Laukkanen, Kari 1964. Kuusalun ja Simititsan sananparsistoa itämerensuomalaisessa perinnekentässä. Fol. Hki.

Holstila, Liisa 1965. Havaintoja kieltosutkautuksista ja -tokaisuista. Fol. Hki.

Leino, Pentti 1965. Suomalaisen sananparsiston alkusointuisuudesta. Fol. Hki.

Laaksonen, Eeva 1965. Sanaleikeistä humoristisena ilmaisukeinona sananparsiesimerkistön mukaan. Fol. Hki.

Appelgrén, Henni 1966. Eläinten roolit suomalaisessa kansanperinteessä. Fol. Hki.

Kuusi, Anna-Leena 1968. Aleksis Kiven fraseologia 'Nummisuutarien' ja 'Canzion' valossa. Fol. Hki.

${ }^{\mathrm{H}}$ Esitelmiä suomalaisen ja vertailevan kansanrunoudentutkimuksen proseminaarissa vuosina 1958-1961,

Laakso, Maija 1958. Ei ole vuohi eläin eikä piika ihminen.

Nahkuri Outi. 1959. Paljon sillä pitää jauhoja olla, joka jokaisen suun tukkii.

Nirvi, Irma 1959. Lavian sananlaskuväärennökset.

Tiusanen, Seija 1959. Rinnastussananparret.

Vuolle, Marja-Liisa 1959. Naisen itku ja sananparret.

Paavolainen, Tytti 1959. Sotkamolaiset wellerismit.

Rissanen, Mauno 1960. Siinä susi, missä mainitaan. Kansainvälinen sananlasku.

Vento, Urpo 1961. Merellä silmät, metsällä korvat.

Suhonen, Seppo 1961. Virolaissuomalaisia vertauksia.

Neimala, Kaisa 1961. Hippa-Heikki.

Taulo, Tuula 1961. Rooman perintö Suomen sananlaskuissa.

Tönkyrä, Anneli 1961. Ironiset vertaukset.

I HAKAMIES, PEKKA 1986: Venäläisten sananparsien vaikutus karjalaiseen ja suomalaiseen sananparsistoon. Helsinki: SKS. Fol.

${ }^{J}$ Hakamies, Pekka 1982. Venäläisten sananparsien vaikutus karjalaiseen ja suomalaiseen sananparsistoon. Fol. Hki Harvilahti, Lauri. 1982. Sananlaskujen rakenteellisen ja sisällöllisen vastaavuuden ongelmista. Fol. Hki.

Laukkanen, Kari 1988. Kuusalun sananlaskut virolais-suomalaisessa perinnekentässä. Fol. Hki.

${ }^{\mathrm{K}}$ Hakamies, Pekka 1980. Venäläisten sananparsien vaikutus karjalaiseen ja suomalaiseen sananparsistoon. Fol. Hki. Harvilahti, Lauri 1980. F. L. Čelakovskýn Mudroslovi-teokseen sisältyvien venäläisten ja puolalaisten varoitussananlaskujen formula-analyysi. Fol. Hki

Savolainen, Maarit 1988. Sananlaskut talonpoikaisnaisen elämänkaaren kuvaajina. Fol. Jkylä.

${ }^{\mathrm{L}}$ Paremiologia:. PAAJANEN, TIMO 1995: Scribal treatment of the literary and vernacular proverbs of al-Mustatraf in 15th-17th century manuscripts with special reference to diglossic variation. Helsinki : Societas Orientalis Fennic.

${ }^{M}$ Piispa, Jyrki 1996. Laiska sananlaskuissa - näkökulmia suomalaiseen laiskuuteen. Fol. Joensuu.

Marttunen, Mira 1997. Sananlaskuista kaunokirjallisessa kontekstissa kaunokirjallisissa monologeissa ja dialogeissa esiintyvien sananlaskujen tarkastelua Pentti Haanpään Jutut-novellikokoelman kontekstin perusteella. Fol. Hki.

N STARK, EIJA 2011: Köyhyyden perintö: Tutkimus kulttuurisen tiedon sisällöistä ja jatkuvuuksista suomalaisissa elämäkerta-ja sananlaskuaineistoissa. Helsinki: SKS.

${ }^{O}$ Paremiologia: LAUHAKANGAS, OUTI 2004: Puheesta ihminen tunnetaan. Sananlaskujen funktiot sosiaalisessa vuorovaikutuksessa. Helsinki: SKS.

GRANBOM-HERRANEN, LIISA 2008: Sananlaskut kasvatuspuheessa - perinnettä, kasvatusta, indoktrinaatiota? Jyväskylän yliopisto.

${ }^{\mathrm{P}}$ Esim. Pettersson, Nancy 2000. "Flit ger bröd men lättja nöd": Ordspråk om pengar, rikedom och fattigdom tagna ur Finlands svenska folkdiktning. Fol. ÅA.

Iranto, Annamari 2001."Tämä maailma on kiperä ja väärä niin kuin pukin sarvi" -lakiin ja oikeuteen liittyvä epäoikeudenmukaisuuden kokemus sananparsissa ja toimittaja Hannu Karpolle lähetetyissä kirjallisissa yhteydenotoissa. Fol. Joensuu.

Korhonen, Johanna 2001. Sääenteet sananparsien valossa. Fol. Tku.

Granbom-Herranen, Liisa 2004. Sananlaskujen käyttäjät ja käyttöyhteys. Sananlaskut käyttökontekstissaan 'Perinne elämässäni' -kilpakirjoituksen aineistossa. Fol Hki. 